УДК 811.111

DOI https://doi.org/10.26661/2414-1135-2021-82-22

\title{
КОГНІТИВНІ ДИФЕРЕНЦЙНІ ОЗНАКИ ЯДЕРНИХ ВЕРБАЛІЗАТОРІВ КОНЦЕПТУ TRAUMA
}

\author{
Мамай Ю. Ю. \\ викладач англійської мови \\ Запорізький державний медичний університет \\ пр. Маяковського, 26, Запоріжжя, Україна \\ orcid.org/0000-0001-7587-3672 \\ juliiamam@gmail.com
}

Ключові слова: когнітивна лінгвістика, кониеетт, травма, ядерний вербалізатор, диференційна ознака.
Взаємовідносини мислення i мови протягом тривалого часу досліджуються різними науковими напрямами. Когнітивна лінгвістика, яка розглядає мову як засіб вербалізації думок, передачі інформації, інструмент за призначенням якого можна краще зрозуміти природу когнітивних процесів у мисленні людини, займає окреме місце поряд iз психологією, психіатрією, медициною, соціологією. Лінгвістичний аналіз допомагає краще зрозуміти, які саме асоціації викликають певні слова, вирази або явища у свідомості носіїв, які проживають у спільноті, мають схожу історію, культурний розвиток, спілкуються однією мовою. Концепт TRAUMA, який знаходиться нині в полі інтересу медичного, публіцистичного, психологічного дискурсів, потребує ретельного вивчення когнітивною лінгвістикою для того, щоб зрозуміти причину зростаючої популярності. Статтю присвячено аналізу визначень «категорія», «класифікатор», «когнітивні ознаки» в рамках лінгвокультурного і лінгвокогнітивного підходів. На основі теоретичних знань виокремлено когнітивні диференційні ознаки ядерних вербалізаторів концепту TRAUMA для розуміння того, як людина розрізняє цей концепт, коли декодує слово trauma в англійській мові. Теорія номінації О.С. Кубрякової, лінгвокультурний підхід 3.Д. Попової i Й.А. Стерніна та Дж. Лакоффа вказують на технології досліджень концептів, виділяючи універсальні когнітивні категорії, які притаманні усім концептам, класифікаційні, шляхом аналізу яких можна виокремити диференційні ознаки ядра іпериферії концепту. На основі цих теоретичних засад у статті застосовано методологію когнітивного диференційного аналізу ознак ядерних вербалізаторів концепту TRAUMA взятих iз 6 сучасних лексико-графічних джерел для встановлення образів, які закріплені в людській свідомості стосовно травмувальних подій, умов скоєння травми, діючих осіб, наслідків і характеристики досвіду, який формується через інтерпретацію навколишнього середовища, коли людина перебуває у стані крайнього шоку, несподівано неприємних почуттів і переживань. Отриманий матеріал буде доданим до аналізу контекстуальної актуалізації концепту TRAUMA у творах «Олівія Кіттерідж», «І знов Олівія» для визначення індивідуально-авторського концепту TRAUMA письменницею Є. Страут. 


\title{
COGNITIVE DIFFERENTIAL FEATURES OF CENTRAL VERBALIZERS IN THE CONCEPT OF TRAUMA
}

\author{
Mamai Yu. Yu. \\ English Language Teacher \\ Zaporizhzhia State Medical University \\ Mayakovsky avenue, 26, Zaporozhzhia, Ukraine \\ orcid.org/0000-0001-7587-3672 \\ juliiamam@gmail.com
}

Key words: cognitive linguistics, concept, trauma, central verbalizer, differential features of the concept.
The relationship between thinking and speech has been studied with various scientific-based approaches for a long time. Cognitive linguistics, which considers language as a means to verbalize thoughts, transmit information, and also as an important key for better understanding of the nature of cognitive processes in human thinking, ranks equally with psychology, psychiatry, medicine, sociology in human mind studying. Linguistic analysis helps to understand better which associations cause certain words, expressions or phenomena in the minds of speakers living in the community, having similar history, cultural development, communicating in the same language. The TRAUMA concept, which is currently being researched from different scientific directions, requires careful study of cognitive linguistics in order to understand the reason for its growing popularity. The article is devoted to the analysis of the definitions "category", "classifier", "cognitive features" in the framework of linguocultural and linguo-cognitive approaches. Based on the theoretical knowledge of three scientific styles, the cognitive differential features of central verbalizers in the TRAUMA concept are highlighted in order to understand typical features a person relies on during decoding the concept of trauma in English. The Helen Kubryakova's Nomination Theory, the linguocultural approach of S.D. Popova and I.A. Sternin, and J. Lakoff point to the technologies of concept research, determing the universal cognitive categories inherent in all concepts, classification categories, by analyzing which it is possible to distinguish the differential features of the concepts centre and periphery. The article uses the cognitive differential methodology to analyse the features of central verbalizers in the TRAUMA concept based on 6 modern lexico-ghaphic sources to establish images that are fixed in consciousness regarding traumatic events, conditions of committing a trauma, actors, consequences and explanation of the experience, which is gaining through the interpretation of the environment, being in a state of extreme shock, unexpectedly unpleasant feelings. The material of this article will be used to carry out the contextual actualization of the TRAUMA concept in the works "Olivia Kitteridge", "And Olivia Again" to determine the individual author's concept of TRAUMA, understanding the peculiarities of the trauma worldview by the writer E. Straut.
Постановка проблеми. Як зазначав Р. Лангакер, когнітивна (теоретична) лінгвістика стала свого роду об'ємним інтелектуальним напрямом, стилем, який виник у XX столітті і не втрачає своєї актуальності дотепер. Розглядання мови як системи вираження та виокремлення символічної та інтерактивної функцій стало можливим через виділення і дослідження феномена категоризації, який притаманний людській свідомості. У гештальт психології з'явились перші роботи, спрямовані на визначення категоризації, які надалі в когнітивній лінгвістиці започатковують традицію вивчення когнітивних механізмів, пов'язаних із людською свідомістю та варіантами відображення когнітивного апарату в мовленні $[1$, с. 3,16$]$.

Серед сучасних наукових праць, які розкривають суть цієї проблеми, варто виділити роботи О.С. Кубрякової, З.Д. Попової, Й.А. Стерніна, Дж. Лакоофа, Р. Лангакера та В. Еванс [1-4; 6], які використовують лінгвокогнітивний та лінгвокультурний напрями для дослідження концептів. Спираючись на майже віковий досвід застосування цих технологій для дослідження структури концептів, стаття присвячена аналізу когнітивно- 
диференційних ознак ядерних вербалізаторів концепту TRAUMA, оскільки на сучасному етапі цей концепт активно використовується в різних дискурсах через потребу кращого розуміння психічного, когнітивного устрою людини.

Аналіз сучасної світової наукової літератури, а саме робіт B. Bush та T. McNamara [6], які активно займаються вивченням мови травми в напрямі прикладної лінгвістики, R. Lakhurst [7], який дослідив історичний розвиток поняття травми 3 психіатричного, правового та соціально-політичного напрямів, вказують на необхідність осягнення концепту TRAUMA когнітивною лінгвістикою, оскільки саме кросдисциплінарне вивчення уможливлює отримання якісних, об'ємних та неупереджених знань.

3 цього випливає актуальність дослідження концепту TRAUMA саме в руслі когнітивної лінгвістики як важливого об'єкта концептосфери, оскільки вищезгадані наукові напрями не в змозі проаналізувати в повній мірі мову постраждалих, відсутність потрібних слів, художні засоби, які передають травмувальний досвід. Когнітивне вивчення значень ядерних вербалізаторів концепту дозволяє висвітлити когнітивний зміст концепту, встановлюючи диференційні і класифікаційні ознаки, які вказують на збільшення людського досвіду, набуття нових знань та змін у дійсності.

Метою статті $€$ встановлення когнітивних диференційних ознак концепту TRAUMA. Відповідно до поставленої мети необхідно виконати такі завдання:

1) інвентаризувати прямі вербалізатори концепту TRAUMA;

2) виявити основні ЛСВ прямих вербалізаторів;

3) виділити диференційні ознаки концепту TRAUMA;

4) визначити ядро номінативного поля концепту TRAUMA.

Об'єктом дослідження $є$ когнітивно-диференційні ознаки ядерних вербалізаторів, а предметом дослідження виступають когнітивнодиференційні ознаки ядерних вербалізаторів концепту TRAUMA.

Виклад основного матеріалу. Діяльність когнітивної лінгвістики втілюється у генеративному та когнітивному напрямах дослідження. Перший займається діючими принципами людської мови. Другий напрям пов'язаний із загальними правилами мови, які слугують інструментами для розуміння принципів роботи свідомості та мозкової діяльності людини. Мова виступає «вікном» для досліджень концептуальних структур: репрезентація знань, структурування та організація концептів та концептуалізація - значення конструк- цій. Лінгвістичні універсалії - поширені моделі, присутні в багатьох мовах, - одиниці мислення, категорії мислення, притаманні усім людям $[1$, c. 54]. Концепт стає головною одиницею функціонування ментальної і мовної систем, через що вважаємо за доцільне детальніше зупинитись на варіантах його визначення.

Вважається, що середньовічний логік П. Абеляр започаткував традицію використання поняття концепту для позначення індивідуальних форм охоплення і розуміння змісту (conceptio) під час роботи 3 текстами Біблії [8, с. 7]. Концепт видавався логіко-лінгвістичною категорією, яка пов'язувала світ думок і світ буття, але втім могла бути і викривленим образом дійсності [9, с. 454-456]. Абеляр наголошував на значенні адресованого слова в процесі мовлення, яке формується під впливом чуттєвого досвіду та уяви [8, с. 143].

С.О. Аскольдов у 1928 р. вперше на вітчизняному просторі використав концепт для пояснення семіотичної функції заміщення (субституції) словесного знака [10, с. 269-273].

У таблиці 1 представлені сучасні варіанти трактування поняття концепту. В основі когнітивних ознак концепту знаходиться категоризація. Під категоризацією розуміють усвідомлення об’єктів та явищ дійсності в загальному змісті або в рамках категорій $[2$, с. 7$]$.

3 огляду на особливості процесу усвідомлення дійсності людиною стає зрозумілою необхідність категоризації - встановлення спільних і відмінних рис між фрагментами дійсності, виділення когнітивно-класифікаційних ознак в окремих концептах, групах концептів, концептосфері. Саме під час такого встановлення відбувається формування узагальнюючого поняття, яке може, хоч і не завжди, закріплюватись словом [3, с. 127].

У межах одного концепту існують як диференційні, так і когнітивно-класифікаційні ознаки. Когнітивна диференційна ознака визначається як окрема ознака об'єкта, яка усвідомлюється людиною та відображається окремим елементом змісту у структурі концепту, а когнітивно-класифікаційна ознака своєю чергою представлена компонентом змісту концепту, який відображає певний аспект, параметр категоризації об'єкта чи явища дійсності та узагальнює однорідні диференційні ознаки в структурі концепту [3, с. 128].

Дж. Лакофф наголошував, що саме досвід $\epsilon$ рушійною силою, яка дає змогу класифікувати дійсність, досвід відображає «експеренціальний, образний, екологічний аспекти мислення», i саме тому ввів термін «класифікатор» [11, с. 12-21]. Класифікатором є ментальна категорія мислення, яка впорядковує, об'єднує, диференціює і відображає процеси у мові, виступаючи інтегральними чи диференційними семами [3, с. 128]. 
Таблиця 1

Варіанти визначення поняття «концепт», структура концепту, способів категоризації

\begin{tabular}{|c|c|c|c|c|}
\hline Автор & \multicolumn{2}{|c|}{ Е.С. Кубрякова [2, с. 102]. } & $\begin{array}{l}\text { 3.Д. Попова, } \\
\text { Й.А. Стернин [3] }\end{array}$ & $\begin{array}{c}\text { Дж. Лакофф } \\
{[4, \text { с. 359-360] }}\end{array}$ \\
\hline Визначення & \multicolumn{2}{|c|}{$\begin{array}{c}\text { Концепт - оперативна одиниця у } \\
\text { розумових процесах, самостійний, } \\
\text { окремий гештальт }\end{array}$} & $\begin{array}{l}\text { Концепт - квант } \\
\text { структурованого } \\
\text { досвіду }\end{array}$ & $\begin{array}{c}\text { Гештальт (концепт) } \\
\text { - структури, } \\
\text { якими керуються } \\
\text { мовні, розумові, } \\
\text { перцептивні та }\end{array}$ \\
\hline \multirow[b]{2}{*}{$\begin{array}{l}\text { Спосіб } \\
\text { категоризація } \\
\text { дійсності }\end{array}$} & $\begin{array}{c}\text { Відбивно } \\
\text { орієнтовний }\end{array}$ & $\begin{array}{c}\text { Вербально } \\
\text { орієнтовний }\end{array}$ & \multirow{2}{*}{$\begin{array}{c}\text { Спільні і відмінні } \\
\text { риси між фрагментами } \\
\text { дійсності (когнітивно- } \\
\text { класифікаційні і } \\
\text { диференційні ознаки) }\end{array}$} & \multirow[b]{2}{*}{$\begin{array}{c}\text { Ментальні } \\
\text { класифікатори }\end{array}$} \\
\hline & $\begin{array}{c}\text { Для впорядкування } \\
\text { побутового, } \\
\text { позамовного світу - } \\
\text { знання про світ }\end{array}$ & $\begin{array}{c}\text { Для структурування } \\
\text { мови та їі системи - } \\
\text { знання про мову }\end{array}$ & & \\
\hline $\begin{array}{l}\text { Структура } \\
\text { концепту }\end{array}$ & \multicolumn{2}{|c|}{$\begin{array}{c}\text { Ономасіологічна модель: } \\
\text { Ономасіологічний базис, ономасіологічна } \\
\text { ознака } \\
\text { Частини мови як прототипові категорії }\end{array}$} & Ядро-периферія & $\begin{array}{c}\text { Пропозиційна модель } \\
{[11, \text { с. } 21]}\end{array}$ \\
\hline
\end{tabular}

Вищезгадані когнітивні ознаки, або класифікатори, поділяються на 1) універсальні, притаманні усім концептам, 2) класифікаційні ознаки класів більш вузькі, які описують певні види фактів, та 3) групові - обмежені певною групою явищ і предметів [3, с. 130-131]. Як стає зрозумілим із подальшого аналізу 6 сучасних лексико-графічних джерел (табл. 2), у концепті TRAUMA наявні універсальні суперкласифікуючі когнітивні ознаки, такі як часова характеристика - довготривалість наслідків травми, загальна негативна оцінка концепту та присутні в ньому емоції страждання, пригніченості. Iз класифікаційних ознак класів присутні усі три: 1) артефакти (яким саме предметом наноситься травма), 2) ментефакти (середовище існування травми, тобто фізичне і психічне тіло людини, пошкоджена ділянка), 3) натурфакти - соціальні умови переживання психологічної травми, класифікування постраждалих за типами травм.

Семемний аналіз ключових слів концепту TRAUMA довів розмежування значення слова trauma на метальну і фізичну складові частини в семантичному просторі носіїв англійської мови. У чотирьох джерелах визначення психічної травми стоїть першою і другою дефініцією iз трьох запропонованих $[12 ; 13 ; 14]$. В останніх двох на перше місце виходить фізична травма [15; 16$]$ і надається четверте значення слова trauma, метафорично уособлюючи заподіювача травми.

Спираючись на дані з таблиці 2, ми виділили 4 ключових слова - ядерних вербалізатора концепту TRAUMA: "shock" («цок»), "раin" («біль»), "wound" («рана»), "injury" («поранення»), на основі яких були виділені когнітивні диференційні ознаки (таблиця 3).
Семантемам лексичної одиниці shock притаманні такі диференційні ознаки:

1. «непередбачуваність подіï» - "suddenness" («несподіваність»), “surprise" («раптовість»), “jolt”'(«потрясіння»);

2. «неприємність того, щзо трапилось» "upsetting", "unpleasant", "painful", "distressing" («засмучуючий», «неприємний», «болісний», «гнітючий»);

3. «насильницький характер дій» - "violent blow", "violent impact" («жорстокий напад, вплив»);

4. «порушення звичного стану» стосується як фізичного, так і психічного здоров'я - “disturbance of the mind or sensibilities", "commotion" («розлад свідомості», «плутанина»).

Лексичне значення одиниці pain об'єктивує такі класифікаційні ознаки:

1. «фізичний дискомфорт» - "severe physical discomfort", "ache" («біль»), "anguish" («страждання»), “disease” («хвороба»);

2. «неспроможність звичайного функціонування» - "bodily disorder" («порушення роботи miлa») та лексико-семантичний варіант shock (4), який стосується фізичного стану індивіда;

3. «усвідомлення та виокремлення руйнівних проиесів на рівні свідомості» - "етоtional distress" («моральні збитки»), "mental suffering" («психічні страждання»)

Лексема wound вербалізує найбільшу кількість диференційних ознак:

1. «тілесні ушкодження загалом» - “damage to part of your body";

2. вказує на «зброю, якою завдається шкода»-“bullet holes" («кульовий отвір»), "knife cuts" («ножове поранення»;) 
3. «жорстокість, внаслідок якої з'являються страждання» - "torture" («тортури»), “malice" («злий намір») і також риси, притаманні лексико-семантичному варіанту pain (1);
4. «жорстокість з боку насильника»- "violance" («насилля»), "abuse" («жорстоке поводження»), "acts of cruelty" («акти насильства»);

Таблиця 2

\section{Словникові визначення терміна trauma}

\begin{tabular}{|c|c|c|c|c|c|}
\hline $\begin{array}{l}\text { 光 } \\
\text { 总 } \\
\text { 岂 }\end{array}$ & Collins Dictionary & $\begin{array}{l}\text { Longman } \\
\text { Dictionary }\end{array}$ & Oxford Dictionary & $\begin{array}{l}\text { Roget's } 21^{\text {st }} \\
\text { Century } \\
\text { Thesaurus }\end{array}$ & Webster's dictionary \\
\hline $\begin{array}{l}\text { 嵒 } \\
\text { 离 } \\
\text { 莺 } \\
\text { m }\end{array}$ & $\begin{array}{l}\text { "a very severe shock } \\
\text { or very upsetting } \\
\text { experience, which } \\
\text { may cause } \\
\text { psychological } \\
\text { damage" }\end{array}$ & $\begin{array}{l}\text { "an unpleasant } \\
\text { and upsetting } \\
\text { experience that } \\
\text { affects you for a } \\
\text { long time" }\end{array}$ & $\begin{array}{l}\text { "a mental condition } \\
\text { caused by severe } \\
\text { shock, especially } \\
\text { when the harmful } \\
\text { effects last } \\
\text { for a long time" }\end{array}$ & $\begin{array}{c}\text { "a body wound or } \\
\text { shock produced } \\
\text { by sudden } \\
\text { physical injury, as } \\
\text { from violence or } \\
\text { accident" }\end{array}$ & $\begin{array}{c}\text { "an injury (such as a } \\
\text { wound) to living tissue } \\
\text { caused by an extrinsic } \\
\text { agent" }\end{array}$ \\
\hline 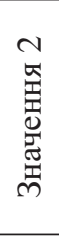 & $\begin{array}{l}\text { "a powerful shock } \\
\text { that may have long- } \\
\text { lasting effects" }\end{array}$ & $\begin{array}{l}\text { "a mental state } \\
\text { of extreme shock } \\
\text { caused by a } \\
\text { very frightening } \\
\text { or unpleasant } \\
\text { experience" } \\
\end{array}$ & $\begin{array}{l}\text { "an unpleasant } \\
\text { experience that } \\
\text { makes you feel } \\
\text { upset and/or } \\
\text { anxious" }\end{array}$ & $\begin{array}{l}\text { "an experience } \\
\text { that produces } \\
\text { psychological } \\
\text { injury or pain." }\end{array}$ & $\begin{array}{l}\text { "a disordered psychic or } \\
\text { behavioral state resulting } \\
\text { from severe mental } \\
\text { or emotional stress or } \\
\text { physical injury" }\end{array}$ \\
\hline 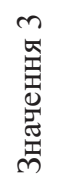 & $\begin{array}{c}\text { "any bodily injury or } \\
\text { wound" }\end{array}$ & "an injury" & "an injury" & & "an emotional upset" \\
\hline 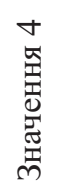 & & & & & $\begin{array}{l}\text { "an agent, force, or } \\
\text { mechanism that causes } \\
\text { trauma" }\end{array}$ \\
\hline
\end{tabular}

Таблиця 3

Лексеми-репрезентанти концепту TRAUMA

\begin{tabular}{|c|c|c|}
\hline Лексема & Лексико-семантичний варіант & Когнітивні диференційні ознаки \\
\hline "shock" & $\begin{array}{l}\text { "something suddenly happens which is unpleasant, } \\
\text { upsetting, or very surprising" [14]. } \\
\text { "a sudden and violent blow or impact"; } \\
\text { "a sudden or violent disturbance or commotion": } \\
\text { "a sudden or violent disturbance of the mind, emotions, } \\
\text { or sensibilities" [15] }\end{array}$ & $\begin{array}{l}\text { 1. «несподіваність», «раптовість», } \\
\text { «потрясіння»; } \\
\text { 2. «неприємність того, що трапилось»; } \\
\text { 3. «насильниџький характер дій»; } \\
\text { 4. «порушення звичного стану» }\end{array}$ \\
\hline „pain“" & $\begin{array}{l}\text { 1. "a localized or generalized unpleasant bodily sensation } \\
\text { or complex of sensations that causes mild to severe } \\
\text { physical discomfort and emotional distress and typically } \\
\text { results from bodily disorder (such as injury or disease)" } \\
\text { 2. "mental or emotional distress or suffering" [16]. }\end{array}$ & $\begin{array}{l}\text { 1. «різичний дискомфорт»; } \\
\text { 2. «неспроможність звичайного } \\
\text { функиіонування»; } \\
\text { 3. «усвідомлення та виокремлення } \\
\text { руйнівних процесів на рівні свідомості» }\end{array}$ \\
\hline „wound“ & $\begin{array}{l}\text { 1. "A wound is damage to part of your body, especially a } \\
\text { cut or a hole in your flesh, which is caused by a gun, knife, } \\
\text { or other weapon." } \\
\text { 2. "a lasting bad effect on someone's mind or feelings } \\
\text { caused by a very upsetting experience" [14] }\end{array}$ & $\begin{array}{l}\text { 1. «тілесні ушкодження загалом»; } \\
\text { 2. «зброя, якою завдається шкода»» } \\
\text { 3. «жорстокість, внаслідок якої } \\
\text { 3'являються страждання»; } \\
\text { 4. «жорстокість із боку насильника»; } \\
\text { 5. «тривалий пригнічений стан» }\end{array}$ \\
\hline „injury“ & $\begin{array}{l}\text { 1. "damage done to a person's or an animal's body" } \\
\text { 2. "to be badly upset by something" [14] } \\
\text { 3. "an agent, force, or mechanism that causes trauma" [16] }\end{array}$ & $\begin{array}{l}\text { 1. «руйнування фізичної форми»; } \\
\text { 2. «гнітючість страждання»; } \\
\text { 3. («діяч, сила, механізм, який } \\
\text { спричинює травму» }\end{array}$ \\
\hline
\end{tabular}


5. «тривалий пригнічений стан» - "a lasting bad effect on someone's mind or feelings caused by a very upsetting experience".

Лексема injury обмеженіше виражає ознаки концепту TRAUMA, зазначаючи лише дві групи явищ:

1) констатує «руйнування фізичної форми»"damage done to a person's or an animal's body" («икода заподіяна живій істоті») як і у випадку shock (4), pain (3), ,wound" (1);

2) описує «гнітючість страждання» - "to be badly upset by something” («стан засмученості»), так само як shock (2), pain (3), wound (5).

Цікавим випадком слугує дефініція лексеми injury - "an agent, force, or mechanism that causes trauma” («діяч, сила, механізм, який спричинює травму»), яка містить метонімічне значення і активізує одразу кілька вербалізаторів концепту shock, pain, wound. Прототип концепту TRAUMA можна відобразити шляхом об'єднання проаналізованих диференційно-когнітивних ознак, які передають унікальність концепту яскравістю концептуальних рис. Кожна лексема із 4 містить інформацію щодо неприємності, дискомфорту, стану розгубленості через несподівану подію. Наслідки травми в суб' єкта можуть проявлятись на психологічному, фізичному або одночасно на обох рівнях, які характеризуються неспроможністю постраждалого функціонувати у звичних обставинах життя. Травма змінює погляди на життя, впливає на спроможність приймати рішення, подальший розвиток. Той, кому була заподіяна шкода, насилля, страждає від страху ймовірності повторних жорстоких дій, намагається уникнути гнітючості страждання. Одужання від травми потребує довгого часу та інколи може бути лише частковим. 15 вищеописаних вербалізаторів становлять ядро номінативного поля. Вони безпосередньо описують риси цього концепту в англомовній картині світу, відображеній у свідомості носіїв англійської мови. Концепт TRAUMA у своєму ядрі містить дані про обставини отримання травми, i․ учасників, жорстокість, насильницький характер, зброю, якою завдається травма, порушення звичного перебігу подій, довготривалість одужання, переживання страждання, безпомічності, крайнього стресу, вплив на подальше життя.

Висновки і перспективи подальших розробок. Проведене дослідження дає змогу наголосити на тому, що концепт TRAUMA $€$ масштабним і значущим в англомовній картині світу.

Інвентаризація прямих вербалізаторів концепту виявила 4 головні лексеми-репрезентанта: shock (шок), pain (біль), wound (рана), injury (поранення).

Їх подальше дослідження сприяло виявленню основних ЛСВ прямих вербалізаторів. У "pain" та "injury" нараховується 3 ЛСВ, 2 з яких схожі за значенням: ураження організму, яке не дозволяє повноцінно функціонувати, усвідомлення страждання. Відмінними є психологічний складник у "pain" та вказівка на наявність заподіювача травми у "injury". ЛСВ "shock" i "wound" є більш розгалуженими: "shock" єдина вказує на раптовість, несподіваність неприємної події у наслідок насильства, а "wound" висвітлює, окрім вищезазначених трьох спільних ознак "shock", "pain" та "injury", навмисний характер завдання травми, жорстокість кривдника, його зброю, передусім холодну та вогнепальну, тип отриманої рани ножова рана, кульовий отвір тощо.

Диференційні ознаки концепту TRAUMA виражені варіантом розгортання на психічному чи ментальному рівнях. Це може бути стан крайнього шоку або дискомфорту, неприємність події чи неможливість їх переживання, інформація щодо постраждалого та заподіювача, конкретні предмети, якими завдається травма.

Ядерним класифікаторам концепту TRAUMA характерна яскравість образів, інформаційний зміст головних лексем, варіативність інтерпретаційного поля ЛСВ.

Таким чином, концепт TRAUMA $є$ багатомірним, семантично об'ємним концептом. Перспективою подальшого дослідження концепту TRAUMA ми вважаємо його діахронічний аналіз, встановлення сучасних зв'язків із суміжними дисциплінами, поступове здійснення аналізу контекстуальної актуалізації концепту TRAUMA у творах «Олівія Кіттерідж», «I знов Олівія» для визначення індивідуально-авторського концепту TRAUMA письменниці С. Страут.

\section{ЛІТЕРАТУРА}

1. Evans V., Green M. Cognitive linguistics: An Introduction. Edinburgh: Edinburgh University Press, 2006. 830 p.

2. Кубрякова Е.С. Язык и знание. Москва : Языки славянской культуры, 2004. 560 с.

3. Попова З.Д., Стернин И.А. Когнитивная лингвистика. Москва : АСТ: Восток - Запад, 2007. $314 \mathrm{c}$

4. Лакофф Дж. Лингвистические гештальты. Новое в зарубежной лингвистике. Лингвистическое издание. 1981. № 10. С. 350-368.

5. Langacker R.W. Foundations of cognitive grammar. Theoretical perequisites. Stanford : Stanford University Press, 1987. V. 1. 628 p.

6. Bush B., McNamara T. Language and Trauma: An introduction. Applied Linguistics. 2020. Issue 3. URL: https://academic.oup.com/applij/ article/41/3/323/5821459?searchresult $=1$

7. Lakhurst R. The question of trauma. Lobdon: Routledge (1st ed), 2008. 256 c. https://doi.org/10.4324/9780203607305 
8. Неретина С.С. Слово и текст в средневековой культуре: Концептуализм Петра Абеляра. Москва : Гнозис, 1996. 182 с.

9. Рассел Б. История западной философии. Москва : Миф, 1993. Т. 1.510 с.

10. Аскольдов С.А. Концепт и слово. Русская словесность. От теории словесности к структуре текста. Антология. Москва : 1997. С. 276-279.

11. Лакофф Д. Мышление в зеркале классификаторов. Текст. Новое в зарубежной лингвистике. Лингвистическое издание. 1988. № 23. C. 12-21.

12. Longman Dictionary of Contemporary English Online. URL: https://www.ldoceonline.com/ dictionary/trauma (дата звернення: 03.03.2021)

13. Oxford Advanced Learner's Dictionary. URL: https://www.oxfordlearnersdictionaries.com/ definition/english/ (дата звернення: 03.03.2021)

14. Collins Dictionary. URL: https://www. collinsdictionary.com/dictionary/english/trauma (дата звернення: 03.03.2021)

15. Roget's $21^{\text {st }}$ Century Thesaurus. URL: https:// www.thesaurus.com/browse/trauma?s=t (дата звернення: 03.03.2021)

16. Webster's third new international dictionary of the English language. URL: https://www. merriam-webster.com/dictionary/trauma\#h1 (дата звернення: 08.03.2021)

\section{REFERENCES}

1. Evans V., Green M. (2006) Cognitive linguistics: An Introduction. Edinburgh: Edinburgh University Press. $830 \mathrm{p}$.

2. Kubryakova Ye.S. (2004) Yazyk i znaniye [Language and knowledge]. Moscow: Yazyki slavyanskoy kul'tur. $560 \mathrm{p}$.

3. Popova Z.D., Sternin I.A. (2007) Kognitivnaya lingvistika [Cognitive linguistics]. Moscow : AST: Vostok - Zapad. 314 p.

4. Lakoff G. (1981) Lingvisticheskiye geshtal'ty [Linguistic gestalts]. Novoye $\mathrm{v}$ zarubezhnoy lingvistike. Lingvisticheskoye izdaniye. 1981. № 10. Pp. $350-368$.
5. Langacker R.W. (1987) Foundations of cognitive grammar. Theoretical perequisites. Stanford : Stanford University Press. V. 1. 628 p.

6. Bush B., McNamara T. (2020) Language and Trauma: An introduction. Applied Linguistics. Issue 3. URL: https://academic.oup.com/applij/ article/41/3/323/5821459? searchresult $=1$

7. Lakhurst R. (2008) The question of trauma. London, England: Routledge (1st ed). 256 p. https:// doi.org/10.4324/9780203607305

8. Neretina S.S. (1996) Slovo i tekst v srednevekovoy kul'ture: Kontseptualizm Petra Abelyara [Word and text in medieval culture: Conceptualism of Peter Abelard]. Moscow : Gnozis. 182 p.

9. Russel B. Istoriya zapadnoy filosofii [History of Western Philosophy]. Moscow : Mif, 1993. V. $1.510 \mathrm{p}$.

10. Askol'dov S.A. (1997) Kontsept i slovo. Russkaya slovesnost'. Ot teorii slovesnosti k strukture teksta. Antologiya [Concept and word. Russian literature. From the theory of literature to the structure of the text. Anthology]. Moscow : Pp. 276-279.

11. Lakoff G. (1988) Myshleniye v zerkale klassifikatorov. Tekst. [Thinking in the mirror of classifiers. Text.] Novoye v zarubezhnoy lingvistike. Lingvisticheskoye izdaniye. № 23. Pp. 12-21.

12. Longman Dictionary of Contemporary English Online. (Access date: 03.03.2021). URL: https:// www.ldoceonline.com/dictionary/trauma

13. Oxford Advanced Learner's Dictionary. (Access date: 03.03.2021). URL: https://www.oxfordlearnersdictionaries.com/definition/english/

14. Collins Dictionary. (Access date: 03.03.2021). URL: https://www.collinsdictionary.com/dictionary/english/trauma

15. Roget's $21^{\text {st }}$ Century Thesaurus. (Access date: 03.03.2021). URL: https://www.thesaurus.com/ browse/trauma? $=\mathrm{t}$

16. Webster's third new international dictionary of the English language. (Access date: 03.03.2021). URL: https://www.merriam-webster.com/dictionary/trauma\#h1. 